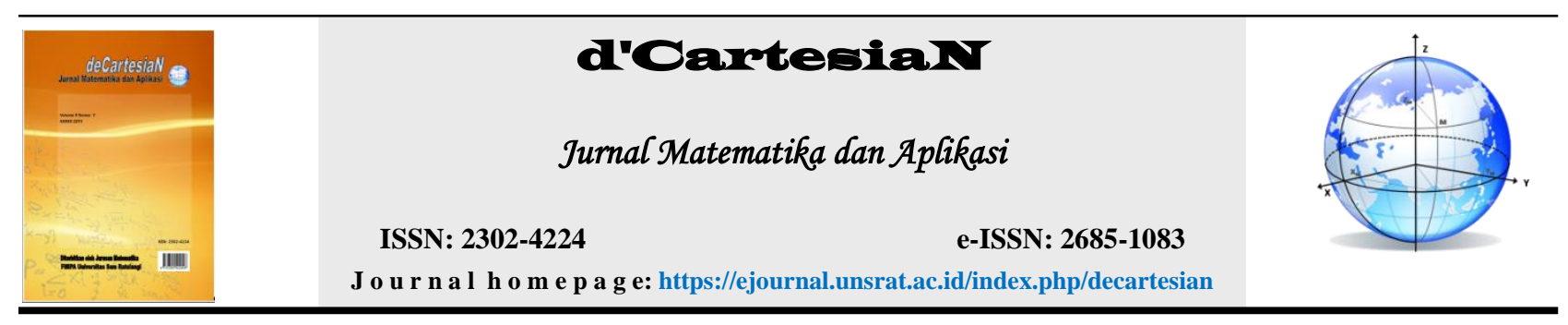

\title{
Penerapan Metode SAW (Simple Additive Weighting) Pada Perankingan SMA-SMA Di Kabupaten Minahasa Selatan
}

\begin{abstract}
Handra R. Sagrang1, Marline S. Paendong1, Altien J. Rindengan ${ }^{*}$
${ }^{*}$ Corressponding author :altien@unsrat.ac.id
\end{abstract}

${ }^{1}$ Jurusan Matematika-Fakultas Matematika dan Ilmu Pengetahuan Alam-Universitas Sam Ratulangi Manado,Indonesia

\section{INFO ARTIKEL}

Diterima : 10 Oktober 2019

Diterima setelah revisi : 23 Oktober 2019

Tersedia online : 28 Oktober 2019

\section{Kata Kunci:}

Minahasa Selatan

Pendidikan

SAW

Sistem Pakar

\section{ARTICLE INFO}

Accepted : 10 October 2019

Accepted after revision : 23 October 2019

Available online : 28 October 2019

\section{Keywords: \\ South Minahasa \\ Education \\ SAW}

Expert System

\section{PENDAHULUAN}

Pendidikan merupakan salah satu faktor terpenting bagi kehidupan setiap manusia untuk memperoleh wawasan yang lebih luas untuk menunjang kehidupan yang lebih baik. Pendidikan di Negara Indonesia merupakan salah satu tujuan Indonesia untuk mencerdaskan kehidupan bangsa yang termuat dalam Pembukaan UUD Republik Indonesia Tahun 1945 [2]. Sehingga untuk menjalankan sistem pendidikan yang merata, maka di buat PP nomor 32 tahun 2013 mengenai standar nasional pendidikan yang terdiri dari 8 standar, yaitu Standar Kompetensi Lulusan, Standar Isi, Standar Proses, Standar Pendidik dan Tenaga Kependidikan, Standar Sarana dan Prasarana, Standar Pengelolaan, Standar Pembiayaan Pendidikan dan Standar Penilaian Pendidikan [4].

Sekolah Menengah Atas (SMA) merupakan jenjang pendidikan pada pendidikan formal di Indonesia setelah lulus Sekolah Menengah Pertama
(SMP)/sederajat. Sekolah menengah atas ditempuh dalam waktu 3 tahun, mulai dari kelas 10 sampai kelas 12. Pada akhir tahun ketiga (kelas 12), siswa diwajibkan mengikuti Ujian Nasional yang memengaruhi kelulusan siswa.

Metode Simple Additive Weighting (SAW) sering juga dikenal istilah metode penjumlahan terbobot. Konsep dasar metode SAW adalah mencari penjumlahan terbobot dari rating kinerja pada setiap alternatif pada semua atribut. Aplikasi sistem pakar dibangun untuk membantu meranking SMA-SMA di Minahasa Selatan. Sistem pakar ini akan menggunakan metode SAW [6].

\subsection{Kabupaten Minahasa Selatan}

Kabupaten Minahasa Selatan adalah kabupaten baru di Provinsi Sulawesi Utara, Indonesia, dengan ibu kota Amurang yang merupakan pemekaran dari Kabupaten Minahasa. Kabupaten ini diresmikan 
pada tanggal 04 Agustus 2003 oleh Dewan Perwakilan Rakyat Republik Indonesia (DPR RI) bersama dengan Kota Tomohon. Kabupaten dengan luas wilayah 1.484,47 km2 dan jumlah penduduk 209.501 jiwa, memiliki 17 kecamatan, 117 desa/kelurahan.

Infrastruktur yang dimiliki, yaitu: 1) lembaga keuangan yang terdiri dari Bank BRI, BPR, Bank Mandiri, Bank Sulut, BNI, Bank Danamon dan koperasi; 2) sarana pendidikan yang terdiri dari $208 \mathrm{TK}, 249$ SD/MI, 82 SMP/MTs, 37 SMA/SMK/MA; 3) fasilitas kesehatan yang terdiri dari RSUD, puskesmas, puskesmas pembantu, dan klinik $\mathrm{KB}$, dan tenaga paramedis yang memadai; 4) fasilitas telekomunikasi yang terdiri dari sambungan telepon, wartel, telepon, jaringan TV dan radio; serta 5) beberapa fasilitas olahraga [5].

\subsection{Standar Nasional Pendidikan}

Standar Nasional Pendidikan adalah kriteria minimal sistem pendidikan di seluruh wilayah hukum Negara Kesatuan Republik Indonesia. Standar Nasional Pendidikan terdiri dari:

1. Standar Kompetensi Lulusan

2. Standar Isi

3. Standar Proses

4. Standar Pendidik dan Tenaga Kependidikan

5. Standar Sarana dan Prasarana

6. Standar Pengelolaan

7. Standar Pembiayaan Pendidikan

8. Standar Penilaian Pendidikan.

Standar Nasional Pendidikan berfungsi sebagai dasar dalam perencanaan, pelaksanaan, pengawasan pendidikan dalam rangka mewujudkan pendidikan nasional yang bermutu. Sedangkan tujuan Standar Nasional Pendidikan adalah menjamin mutu pendidikan nasional dalam rangka mencerdaskan kehidupan bangsa dan membentuk watak serta peradaban bangsa yang bermartabat [4].

\section{a. Standar Isi}

Standar Isi adalah kriteria mengenai ruang lingkup materi dan tingkat Kompetensi untuk mencapai Kompetensi lulusan pada jenjang dan jenis pendidikan tertentu. standar isi mencakup ruang lingkup materi dan tingkat kompetensi [4].

\section{b. Standar Pendidik dan Tenaga Kependidikan}

Standar Pendidik dan Tenaga Kependidikan adalah kriteria mengenai pendidikan prajabatan dan kelayakan maupun mental, serta pendidikan dalam jabatan [4].

\section{c. Standar Kompetensi Lulusan}

Standar Kompetensi Lulusan adalah kriteria mengenai kualifikasi kemampuan lulusan yang mencakup sikap, pengetahuan, dan keterampilan. Standar Kompetensi Lulusan digunakan sebagai acuan utama Pengembangan Standar Isi, Standar Proses, Standar Penilaian Pendidikan, Standar Pendidik dan Tenaga Kependidikan, Standar Sarana dan Prasarana, Standar Pengelolaan, dan Standar Pembiayaan [4].

\section{d. Standar Penilaian Pendidikan}

Standar Penilaian Pendidikan adalah kriteria mengenai mekanisme, prosedur, dan instrumen penilaian hasil belajar Peserta Didik. Penilaian pendidikan pada jenjang pendidikan dasar dan menengah terdiri atas: 1) Penilaian hasil belajar oleh pendidik; dan 2) Penilaian hasil belajar oleh satuan pendidikan; dan 3) Penilaian hasil belajar oleh Pemerintah [4].

\subsection{Metode SAW}

Metode Simple Additive Weighting (SAW) sering juga dikenal istilah metode penjumlahan terbobot. Konsep dasar metode SAW adalah mencari penjumlahan terbobot dari rating kinerja pada setiap alternatif pada semua atribut. Metode SAW membutuhkan proses normalisasi matriks keputusan (X) ke suatu skala yang dapat diperbandingkan dengan semua rating alternatif yang ada [7].

Langkah-langkah metode SAW yaitu:

1. Menentukan Alternatif (A) dan Kriteria (C), berdasarkan persamaan berikut:

$Z=m \times n$

Dengan:

$$
\begin{array}{ll}
\mathrm{Z} & =\text { Keputusan } \\
\mathrm{m} & =\text { alternatif-alternatif } \\
\mathrm{n} & =\text { kriteria-kriteria }
\end{array}
$$

2. Menentukan bobot masing-masing kriteria (W)

Bobot masing-masing kriteria atau bobot preferensi ditentukan berdasarkan persamaan berikut:

$$
W=w_{1} w_{2} w_{3 \ldots} w_{j}
$$

3. Membentuk tabel keputusan

Tabel keputusan dibuat berdasarkan data yang telah didapat dan siap diolah.

$$
x=\left[\begin{array}{ccc}
x_{11} x_{12} & \cdots & x_{1 j} \\
\vdots & \ddots & \vdots \\
x_{i 1} x_{12} & \cdots & x_{i j}
\end{array}\right]
$$

4. Membentuk matriks keputusan (X) berdasarkan table kepputusan

Setelah diketahui bobot preferensi untuk masingmasing kriteria, maka ditentukan bobot atribut untuk masing-masing kriteria. Data disajikan dalam sebuah matriks

5. Normalisasi matriks keputusan (r)

Formula untuk melakukan normalisasi tersebut dapat dilihat pada persamaan berikut

$$
r_{i j}=\left\{\begin{array}{l}
\frac{x_{i j}}{\max _{i} x_{i j}} ; j \text { ika } \mathrm{j} \text { adalah atribut keuntungan (benefit) } \\
\frac{\min _{i} x_{i j}}{x_{i j}} ; \text { jika } \mathrm{j} \text { adalah atribut biaya (cost) }
\end{array}\right.
$$

Dengan:

$r_{i j} \quad=$ nilai rating kinerja ternormalisasi

$x_{i j} \quad=$ nilai atribut yang dimiliki setiap kriteria

$\operatorname{Max} r_{i j}=$ nilai terbesar dari setiap kriteria $\mathrm{i}$

Min $r_{i j}=$ nilai terbesar dari setiap kriteria $\mathrm{i}$

Benefit = jika nilai terbesar yang terbaik

Cost $=$ jika nilai terkecil yang terbaik

Hasil dari nilai rating kinerja ternormalisasi (Rij) membentuk matriks ternormalisasi (R) seperti pada persamaan berikut:

$$
R=\left[\begin{array}{ccc}
r_{11} r_{12} & \cdots & r_{1 j} \\
\vdots & \ddots & \vdots \\
r_{i 1} r_{i 2} & \cdots & r_{i j}
\end{array}\right]
$$

6. Melakukan perankingan terhadap alternatif (V)

Menentukan nilai preferensi untuk setiap alternatif $\left(\mathrm{V} \_\mathrm{i}\right)$ dengan cara menjumlahkan hasil kali 
antara matriks ternormalisasi (R) dengan nilai bobot preferensi (W) sesuai menggunakan persamaan berikut:

$$
V_{i}=\sum_{j=1}^{n} w_{j} r_{i j}
$$

\section{Dengan:}

$\mathrm{w}_{\mathrm{j}}=$ bobot yang diberikan .

\section{METODE PENELITIAN}

\subsection{Waktu dan Tempat Penelitian}

Penelitian dilakukan pada November 2018 sampai Juni 2019 dan tempat penelitian dilakukan di Laboratorium Komputer Jurusan Matematika.

\subsection{Sumber data}

Data yang akan digunakan dalam penelitian yaitu data sekunder SMA-SMA di Kabupaten Minahasa Selatan. Data yang diambil hanya 11 SMA dari total 19 SMA di Minahasa Selatan karena faktor dana dan jarak untuk mencapai 8 SMA lainnya.

\subsection{Objek Penelitian}

Objek penelitian yaitu SMA-SMA di Kabupaten Minahasa Selatan antara lain SMA Negeri 1 Sinonsayang, SMA Negeri 1 Tenga, SMA Negeri 1 Amurang Barat, SMA Katolik Aquino Amurang, SMA Negeri 1 Amurang, SMA Negeri 1 Amurang Timur, SMA Kristen Alfa Omega Tumpaan, SMA Negeri 2 Tareran, SMA Negeri 1 Tareran, SMA Kristen Suluun, SMA Negeri 1 Tatapaan

\subsection{Variabel Penelitian}

Variabel-variabel yang diamati yaitu:

1. Standar Isi yang meliputi Kurikulum yang digunakan.

2. Standar Pendidik dan Tenaga Kependidikan yang meliputi:

2.1. Jumlah dan kualifikasi masing-masing guru

2.2. Kualifikasi kepala sekolah

2.3. Jumlah dan kualifikasi tenaga administrasi

2.4. Jumlah dan kualifikasi tenaga perpustakaan

2.5. Jumlah dan kualifikasi tenaga laboratorium

2.6. Jumlah dan kualifikasi tenaga kebersihan

3. Standar Kompetensi Lulusan yang meliputi:

3.1. Nilai rata-rata mata pelajaran agama siswa kelas XII

3.2. Nilai rata-rata mata pelajaran Pendidikan Kewarganegaraan kelas XII

3.3. Nilai rata-rata mata pelajaran Bahasa Indonesia kelas XII

3.4. Nilai rata-rata mata pelajaran Bahasa Ingris kelas XII

3.5. Nilai rata-rata mata pelajaran Matematika kelas XII

3.6. Nilai rata-rata mata pelajaran Biologi kelas XII

3.7. Nilai rata-rata mata pelajaran Fisika kelas XII

3.8. Nilai rata-rata mata pelajaran Kimia kelas XII

3.9. Nilai rata-rata mata pelajaran Ekonomi kelas XII

3.10. Nilai rata-rata mata pelajaran Sejarah kelas XII

3.11. Nilai rata-rata mata pelajaran Geografi kelas XII

3.12. Nilai rata-rata mata pelajaran sosiologi kelas XII

3.13. Nilai rata-rata mata pelajaran Seni dan Budaya kelas XII
3.14. Nilai rata-rata mata pelajaran Ketrampilan kelas XII

3.15. Nilai rata-rata mata pelajaran pendidikan jasmani dan olahraga XII

3.16. Nilai rata-rata mata pelajaran Teknologi Informasi dan Komputer kelas XII

3.17. Nilai rata-rata Ujian Nasional lulusan tahun 2018

3.18. Nilai rata-rata UN siswa yang diterima tahun 2018

3.19. Nilai rata-rata siswa kelas $X$

3.20. Nilai Rata-rata siswa kelas XI

3.21. Nilai Rata-rata siswa kelas XII

4. Standar Penilaian Pendidikan yang meliputi nilai standar kriteria ketuntasan minimal (KKM).

\subsection{Proses Analisis dan Perancangan Sistem}

Langkah-langkah dalam proses analisis dan perancangan sistem yaitu :

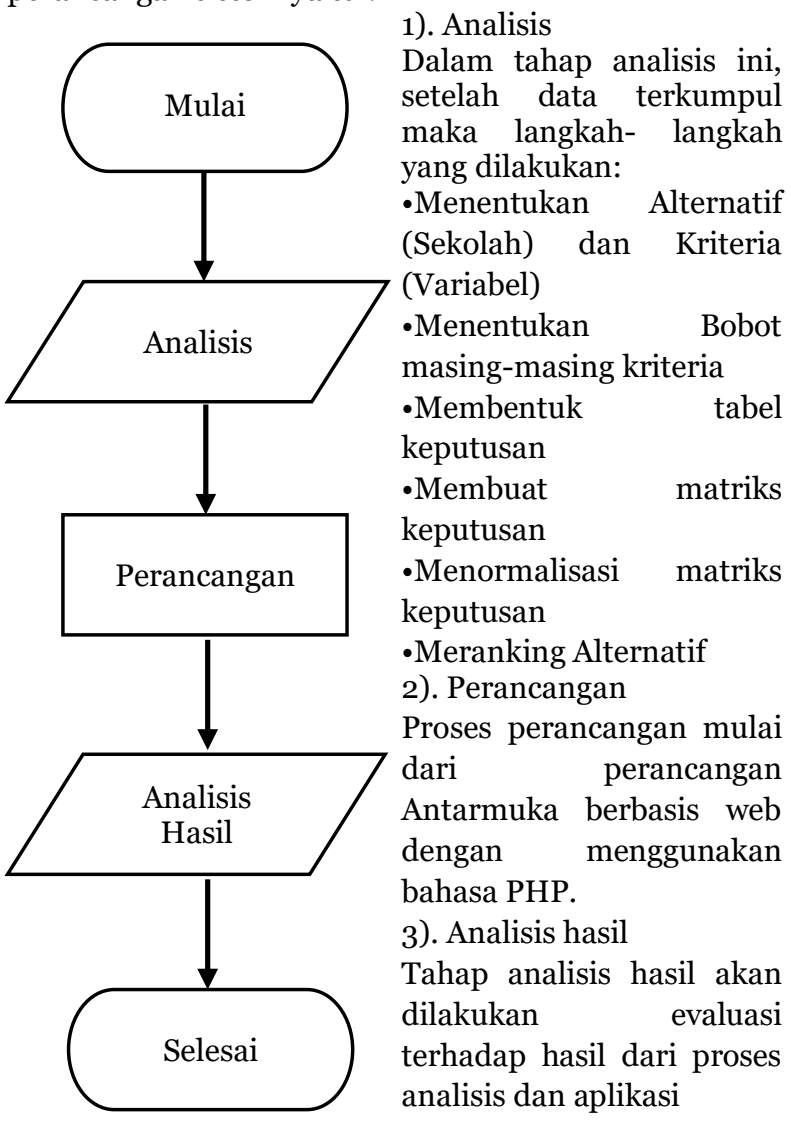

1

3. HASIL DAN PEMBAHASAN

3.1. Menentukan Alternatif dan Kriteria

Alternatif dan kriteria ditentutakan seperti pada persamaan (1). Alternatif penelitian yaitu objek penelitian yang terdiri dari 11 SMA di Kabupaten Minahasa Selatan yang dapat dilihat pada tabel 1.

Tabel 1.Alternatif Penelitian

\begin{tabular}{lll}
\hline No & \multicolumn{1}{c}{ Objek Penelitian } & Simbol \\
\hline 1. & SMA Negeri 1 Sinonsayang & A1 \\
2. & SMA Negeri 1 Tenga & A2 \\
3. & SMA Negeri 1 Amurang Barat & A3 \\
4. & SMA Katolik Aquino Amurang & A4
\end{tabular}




$\begin{array}{lll}\text { 5. } & \text { SMA Negeri } 1 \text { Amurang } & \text { A5 } \\ \text { 6. } & \text { SMA Negeri } 1 \text { Amurang Timur } & \text { A6 } \\ \text { 7. } & \text { SMA Kristen Alfa Omega Tumpaan } & \text { A7 } \\ \text { 8. } & \text { SMA Negeri } 2 \text { Tareran } & \text { A8 } \\ \text { 9. } & \text { SMA Negeri } 1 \text { Tareran } & \text { A9 } \\ \text { 10. } & \text { SMA Kristen Suluun } & \text { A10 } \\ \text { 11. } & \text { SMA Negeri } 1 \text { Tatapaan } & \text { A11 }\end{array}$

Kriteria Penelitian yaitu 29 variabel yang diambil berdasarkan 4 standar nasional pendidikan yang dapat dilihat pada tabel 2.

Tabel 2. Kriteria Penelitian

\begin{tabular}{|c|c|c|}
\hline No & Objek Penelitian & Simbol \\
\hline 1. & Kurikulum yang digunakan & $\mathrm{C} 1$ \\
\hline 2. & $\begin{array}{l}\text { Jumlah dan kualifikasi masing- } \\
\text { masing guru }\end{array}$ & $\mathrm{C} 2$ \\
\hline 3. & Kualifikasi kepala sekolah & $\mathrm{C}_{3}$ \\
\hline 4. & $\begin{array}{l}\text { Jumlah dan kualifikasi tenaga } \\
\text { administrasi }\end{array}$ & $\mathrm{C}_{4}$ \\
\hline 5. & $\begin{array}{l}\text { Jumlah dan kualifikasi tenaga } \\
\text { perpustakaan }\end{array}$ & $\mathrm{C}_{5}$ \\
\hline 6. & $\begin{array}{l}\text { Jumlah dan kualifikasi tenaga } \\
\text { laboratorium }\end{array}$ & C6 \\
\hline 7. & $\begin{array}{l}\text { Jumlah dan kualifikasi tenaga } \\
\text { kebersihan, }\end{array}$ & $\mathrm{C}_{7}$ \\
\hline 8. & $\begin{array}{l}\text { Nilai rata-rata mata pelajaran agama } \\
\text { siswa kelas XII }\end{array}$ & $\mathrm{C} 8$ \\
\hline 9. & $\begin{array}{l}\text { Nilai rata-rata mata pelajaran } \\
\text { Pendidikan Kewarganegaraan kelas } \\
\text { XII }\end{array}$ & C9 \\
\hline 10. & $\begin{array}{l}\text { Nilai rata-rata mata pelajaran Bahasa } \\
\text { Indonesia kelas XII }\end{array}$ & C10 \\
\hline 11. & $\begin{array}{l}\text { Nilai rata-rata mata pelajaran Bahasa } \\
\text { Ingris kelas XII }\end{array}$ & $\mathrm{C} 11$ \\
\hline 12. & $\begin{array}{l}\text { Nilai rata-rata mata pelajaran } \\
\text { Matematika kelas XII }\end{array}$ & $\mathrm{C} 12$ \\
\hline 13. & $\begin{array}{l}\text { Nilai rata-rata mata pelajaran Biologi } \\
\text { kelas XII }\end{array}$ & $\mathrm{C} 13$ \\
\hline 14. & $\begin{array}{l}\text { Nilai rata-rata mata pelajaran Fisika } \\
\text { kelas XII }\end{array}$ & C14 \\
\hline 15 & $\begin{array}{l}\text { Nilai rata-rata mata pelajaran Kimia } \\
\text { kelas XII }\end{array}$ & C15 \\
\hline 16. & $\begin{array}{l}\text { Nilai rata-rata mata pelajaran } \\
\text { Ekonomi kelas XII }\end{array}$ & $\mathrm{C} 16$ \\
\hline 17. & $\begin{array}{l}\text { Nilai rata-rata mata pelajaran } \\
\text { Sejarah kelas XII }\end{array}$ & $\mathrm{C} 17$ \\
\hline 18. & $\begin{array}{l}\text { Nilai rata-rata mata pelajaran } \\
\text { Geografi kelas XII }\end{array}$ & C18 \\
\hline 19. & $\begin{array}{l}\text { Nilai rata-rata mata pelajaran } \\
\text { sosiologi kelas XII }\end{array}$ & $\mathrm{C}_{19}$ \\
\hline 20. & $\begin{array}{l}\text { Nilai rata-rata mata pelajaran Seni } \\
\text { dan Budaya kelas XII }\end{array}$ & $\mathrm{C} 2 \mathrm{O}$ \\
\hline 21. & $\begin{array}{l}\text { Nilai rata-rata mata pelajaran } \\
\text { Ketrampilan kelas XII }\end{array}$ & C21 \\
\hline 22. & $\begin{array}{l}\text { Nilai rata-rata mata pelajaran } \\
\text { pendidikan jasmani dan olahraga XII }\end{array}$ & C22 \\
\hline 23. & $\begin{array}{l}\text { Nilai rata-rata mata pelajaran } \\
\text { Teknologi Informasi dan Komputer } \\
\text { kelas XII }\end{array}$ & C23 \\
\hline 24. & $\begin{array}{l}\text { Nilai rata-rata Ujian Nasional } \\
\text { lulusan tahun } 2018\end{array}$ & C24 \\
\hline 25 & $\begin{array}{l}\text { Nilai rata-rata UN siswa yang } \\
\text { diterima tahun } 2018\end{array}$ & $\mathrm{C} 25$ \\
\hline 26. & Nilai rata-rata siswa kelas $\mathrm{X}$ & C26 \\
\hline 27. & Nilai Rata-rata siswa kelas XI & $\mathrm{C} 27$ \\
\hline 28. & Nilai Rata-rata siswa kelas XII & $\mathrm{C} 28$ \\
\hline 29. & Standar Penilaian Pendidikan & C29 \\
\hline
\end{tabular}

\subsection{Menentukan Bobot masing-masing kriteria}

Untuk mentukan bobot masing-masing kriteria dilakukan survei menggunakan kuesioner pada 100 responden dari berbagai kalangan seperti kepala sekolah, guru dan para lulusan. Data kemudian dirataratakan pada masing-masing kriteria. Lembar kuesioner dapat dilihat pada lampiran 1. Didapat data yang disusun berdasarkan persamaan (2) yaitu pada tabel 3 .

Tabel 3. Bobot masing-masing kriteria

\begin{tabular}{|c|c|}
\hline Objek Penelitian & Bobot \\
\hline C1 & 3.725 \\
\hline $\mathrm{C}_{2}$ & 3.7 \\
\hline $\mathrm{C}_{3}$ & 3.8 \\
\hline $\mathrm{C}_{4}$ & 3.4 \\
\hline $\mathrm{C}_{5}$ & 3.4 \\
\hline C6 & 3.55 \\
\hline $\mathrm{C}_{7}$ & 3.7 \\
\hline $\mathrm{C} 8$ & 4.2 \\
\hline C9 & 3.85 \\
\hline C10 & 3.875 \\
\hline C11 & 3.825 \\
\hline C12 & 3.8 \\
\hline $\mathrm{C} 13$ & 3.775 \\
\hline C14 & 3.7 \\
\hline $\mathrm{C} 15$ & 3.675 \\
\hline $\mathrm{C} 16$ & 3.75 \\
\hline $\mathrm{C} 17$ & 3.7 \\
\hline $\mathrm{C} 18$ & 3.75 \\
\hline C19 & 3.675 \\
\hline $\mathrm{C} 2 \mathrm{O}$ & 4.025 \\
\hline $\mathrm{C} 21$ & 4.025 \\
\hline $\mathrm{C} 22$ & 4.025 \\
\hline $\mathrm{C} 23$ & 4.075 \\
\hline $\mathrm{C} 24$ & 4 \\
\hline $\mathrm{C} 25$ & 3.75 \\
\hline $\mathrm{C} 26$ & 3.85 \\
\hline $\mathrm{C} 27$ & 3.8 \\
\hline $\mathrm{C} 28$ & 3.975 \\
\hline $\mathrm{C} 29$ & 4.025 \\
\hline
\end{tabular}

\subsection{Menentukan Tabel Keputusan}

Tabel keputusan berisi nilai-nilai pada masingmasing sekolah berdasarkan tiap-tiap kriteria dan disusun menurut persamaan (3). Untuk tabel keputusan dapat dilihat pada tabel 4 .

\subsection{Membuat Matriks Keputusan}

Matriks keputusan X adalah data berdasarkan tabel 4 .

\subsection{Menormalisasi Matriks Keputusan}

Normalisasi matriks keputusan adalah hasil olahan data dengan menggunakan persamaan (4) dan berbentuk matriks seperti pada persamaan (5). Karena data yang didapat merupakan atribut keuntungan (benefit) maka didapat data matriks ternormalisasi $\mathrm{R}$ seperti pada tabel 6 .

\subsection{Menormalisasi Matriks Keputusan}

Normalisasi matriks keputusan adalah hasil olahan data dengan menggunakan persamaan (4) dan berbentuk matriks seperti pada persamaan (5). Karena data yang didapat merupakan atribut keuntungan (benefit) maka didapat data matriks ternormalisasi $\mathrm{R}$ seperti pada tabel 6 . 
Handra R. Sagrang, Marline S. Paendong, Altien J. Rindengan

d'Cartesian Jurnal Matematika dan Aplikasi, Vol. 9, No. 1, (Maret 2020): 16-23

Tabel 4. Tabel Keputusan

\begin{tabular}{|c|c|c|c|c|c|c|c|c|c|c|c|}
\hline Objek/Peubah & $\begin{array}{l}\text { SMA } \\
\text { Negeri } \\
1 \\
\text { Sinonsa } \\
\text { yang } \\
\end{array}$ & $\begin{array}{l}\text { SMA } \\
\text { Negeri } \\
1 \\
\text { Tenga }\end{array}$ & $\begin{array}{l}\text { SMA } \\
\text { Negeri } 1 \\
\text { Amuran } \\
\text { g Barat }\end{array}$ & $\begin{array}{l}\text { SMA } \\
\text { Katolik } \\
\text { Aquino } \\
\text { Amuran } \\
\mathrm{g} \\
\end{array}$ & $\begin{array}{l}\text { SMA } \\
\text { Negeri } 1 \\
\text { Amuran } \\
\mathrm{g} \\
\end{array}$ & $\begin{array}{l}\text { SMA } \\
\text { Negeri } 1 \\
\text { Amurang } \\
\text { Timur }\end{array}$ & $\begin{array}{l}\text { SMA } \\
\text { Kristen } \\
\text { Alfa } \\
\text { Omega } \\
\text { Tumpaan }\end{array}$ & $\begin{array}{l}\text { SMA } \\
\text { Negeri } \\
2 \\
\text { Tareran }\end{array}$ & $\begin{array}{l}\text { SMA } \\
\text { Negeri } \\
1 \\
\text { Tareran }\end{array}$ & $\begin{array}{l}\text { SMA } \\
\text { Kristen } \\
\text { Suluun }\end{array}$ & $\begin{array}{l}\text { SMA } \\
\text { Negeri } 1 \\
\text { Tatapaa } \\
\text { n }\end{array}$ \\
\hline Kurikulum yang digunakan & 70 & 80 & 70 & 70 & 80 & 70 & 70 & 70 & 70 & 70 & 70 \\
\hline Jumlah dan kualifikasi masing-masing guru & 23 & 46 & 23 & 52 & 111 & 50 & 9 & 36 & 45 & 9 & 12 \\
\hline Kualifikasi kepala sekolah & 1 & 1 & 2 & 1 & 1 & 2 & 1 & 2 & 1 & 2 & 1 \\
\hline Jumlah dan kualifikasi tenaga administrasi & $\circ$ & 4 & $\circ$ & $\circ$ & 8 & $\circ$ & $\circ$ & 3 & 4 & 3 & 3 \\
\hline Jumlah dan kualifikasi tenaga perpustakaan & $\circ$ & $\circ$ & $\circ$ & 2 & 3 & 2 & 2 & 2 & 3 & $\circ$ & 2 \\
\hline Jumlah dan kualifikasi tenaga laboratorium & $\circ$ & $\circ$ & 1 & 2 & $\circ$ & 1 & $\circ$ & 2 & 2 & $\circ$ & 1 \\
\hline Jumlah dan kualifikasi tenaga kebersihan & $\circ$ & 1 & $\circ$ & 1 & 2 & $\circ$ & $\circ$ & 1 & 1 & $\circ$ & 1 \\
\hline $\begin{array}{l}\text { Nilai rata-rata mata pelajaran agama siswa kelas XII } \\
\text { Nilai rata-rata mata pelajaran Pendidikan Kewarganegaraan kelas }\end{array}$ & 87 & 83 & 89 & 71 & 86 & 84 & 86 & 84 & 87 & 86 & 90 \\
\hline XII & 81 & 82 & 83 & 70 & 82 & 78 & 82 & 78 & 79 & 82 & 85 \\
\hline Nilai rata-rata mata pelajaran Bahasa Indonesia kelas XII & 86 & 82 & 89 & 75 & 83 & 81 & 83 & 81 & 80 & 70 & 85 \\
\hline Nilai rata-rata mata pelajaran Bahasa Ingris kelas XII & 76 & 77 & 83 & 65 & 76 & 73 & 76 & 73 & 72 & 62 & $8_{5}$ \\
\hline Nilai rata-rata mata pelajaran Matematika kelas XII & 85 & 81 & 92 & 74 & 84 & 77 & 84 & 77 & 69 & 77 & 94 \\
\hline Nilai rata-rata mata pelajaran Biologi kelas XII & 87 & 85 & 90 & 76 & 87 & 84 & 87 & 84 & 81 & 82 & 88 \\
\hline Nilai rata-rata mata pelajaran Fisika kelas XII & 82 & 73 & 83 & 71 & 79 & 74 & 79 & 74 & 64 & 66 & 87 \\
\hline Nilai rata-rata mata pelajaran Kimia kelas XII & 82 & $7^{8}$ & 86 & 76 & 82 & 79 & 82 & 79 & 63 & 74 & 90 \\
\hline Nilai rata-rata mata pelajaran Ekonomi kelas XII & 81 & 77 & 85 & 75 & 83 & 78 & 83 & 78 & 62 & 62 & $8_{5}$ \\
\hline Nilai rata-rata mata pelajaran Sejarah kelas XII & 83 & 79 & 86 & 72 & 81 & 75 & 81 & 75 & 81 & 60 & 79 \\
\hline Nilai rata-rata mata pelajaran Geografi kelas XII & 87 & $8_{3}$ & 90 & 76 & 86 & 79 & 86 & 79 & 85 & 60 & 91 \\
\hline Nilai rata-rata mata pelajaran sosiologi kelas XII & 81 & 82 & 87 & 75 & 83 & 78 & 83 & 78 & 84 & 68 & $8_{3}$ \\
\hline Nilai rata-rata mata pelajaran Seni dan Budaya kelas XII & 78 & 76 & 86 & 72 & 82 & 80 & 82 & 80 & 84 & 70 & 84 \\
\hline Nilai rata-rata mata pelajaran Ketrampilan kelas XII & 79 & 77 & 86 & 73 & 83 & 81 & 83 & 81 & 85 & 76 & 86 \\
\hline $\begin{array}{l}\text { Nilai rata-rata mata pelajaran pendidikan jasmani dan olahraga XII } \\
\text { Nilai rata-rata mata pelajaran Teknologi Informasi dan Komputer }\end{array}$ & 81 & 87 & 89 & 75 & 86 & 83 & 86 & 83 & 87 & 81 & 88 \\
\hline $\begin{array}{l}\text { Nilai rata-rata mata pelajaran Teknologi Informasi dan Komputer } \\
\text { kelas XII }\end{array}$ & 79 & 80 & 87 & 73 & 81 & 81 & 81 & 81 & 75 & 60 & 83 \\
\hline Nilai rata-rata Ujian Nasional lulusan tahun 2015 & 82 & 63 & 62 & 65 & 63 & 69 & 63 & 69 & 65 & 67 & 76 \\
\hline Nilai rata-rata UN siswa yang diterima tahun 2015 & 78 & 63 & 83 & 72 & 68 & 60 & 68 & 60 & 64 & 78 & 77 \\
\hline Nilai rata-rata siswa kelas $\mathrm{X}$ & 82 & 68 & 82 & 61 & 72 & 74 & 72 & 74 & 71 & 82 & 76 \\
\hline Nilai Rata-rata siswa kelas XI & 79 & 70 & 80 & 68 & 68 & 76 & 68 & 76 & 70 & 78 & 84 \\
\hline Nilai Rata-rata siswa kelas XII & 83 & 74 & 87 & 77 & 84 & 83 & 84 & $8_{3}$ & 79 & 74 & 89 \\
\hline Standar Penilaian Pendidikan & 75 & 75 & 75 & 70 & 61 & 75 & 75 & 75 & 75 & 75 & 75 \\
\hline
\end{tabular}

Tabel 5. Tabel Matriks Keputusan X

\begin{tabular}{|c|c|c|c|c|c|c|c|c|c|c|c|}
\hline & S1 & S2 & $\mathrm{S}_{3}$ & $\mathrm{~S}_{4}$ & $\mathrm{~S}_{5}$ & S6 & S7 & S8 & S9 & $\begin{array}{c}\text { S1 } \\
\mathrm{O}\end{array}$ & $\begin{array}{c}\mathrm{S} 1 \\
1 \\
\end{array}$ \\
\hline $\mathrm{C} 1$ & 70 & $\begin{array}{l}8 \\
0\end{array}$ & 70 & 70 & 80 & 70 & 70 & 70 & 70 & 70 & 70 \\
\hline $\mathrm{C} 2$ & 23 & 46 & 23 & 52 & $\begin{array}{c}11 \\
1\end{array}$ & 50 & 9 & 36 & 45 & 9 & 12 \\
\hline $\mathrm{C}_{3}$ & 1 & 1 & 2 & 1 & 1 & 2 & 1 & 2 & 1 & 2 & 1 \\
\hline $\mathrm{C}_{4}$ & o & 4 & o & o & 8 & o & 0 & 3 & 4 & 3 & 3 \\
\hline $\mathrm{C}_{5}$ & o & o & 0 & 2 & 3 & 2 & 2 & 2 & 3 & $\mathrm{o}$ & 2 \\
\hline C6 & o & o & 1 & 2 & 0 & 1 & 0 & 2 & 2 & o & 1 \\
\hline $\mathrm{C}_{7}$ & o & 1 & o & 1 & 2 & 0 & 0 & 1 & 1 & 0 & 1 \\
\hline C8 & 87 & 83 & 89 & 71 & 86 & 84 & $\begin{array}{l}8 \\
6\end{array}$ & 84 & 87 & 86 & 90 \\
\hline C9 & 81 & 82 & 83 & 70 & 82 & 78 & 82 & 78 & 79 & 82 & 85 \\
\hline C10 & $\begin{array}{l}8 \\
6\end{array}$ & 82 & 89 & 75 & 83 & 81 & 83 & 81 & $\begin{array}{l}8 \\
0\end{array}$ & 70 & 85 \\
\hline C11 & 76 & 77 & 83 & 65 & 76 & 73 & 76 & 73 & 72 & 62 & 85 \\
\hline C12 & 85 & 81 & 92 & 74 & 84 & 77 & $\begin{array}{l}8 \\
4\end{array}$ & 77 & 69 & 77 & 94 \\
\hline $\mathrm{C}_{13}$ & 87 & 85 & 90 & 76 & 87 & 84 & 87 & 84 & 81 & 82 & 88 \\
\hline C14 & 82 & 73 & 83 & 71 & 79 & 74 & 79 & 74 & 64 & 66 & 87 \\
\hline C15 & 82 & 78 & 86 & 76 & 82 & 79 & 82 & 79 & 63 & 74 & 90 \\
\hline C16 & 81 & 77 & 85 & 75 & 83 & 78 & 83 & 78 & 62 & 62 & 85 \\
\hline $\mathrm{C}_{17}$ & 83 & 79 & 86 & 72 & 81 & 75 & 81 & 75 & 81 & 60 & 79 \\
\hline C18 & 87 & 83 & 90 & 76 & 86 & 79 & $\begin{array}{l}8 \\
6\end{array}$ & 79 & 85 & 60 & 91 \\
\hline C19 & 81 & 82 & 87 & 75 & 83 & 78 & 83 & 78 & 84 & 68 & 83 \\
\hline $\begin{array}{c}\mathrm{C} 2 \\
\mathrm{O}\end{array}$ & 78 & 76 & 86 & 72 & 82 & $\begin{array}{l}8 \\
0\end{array}$ & 82 & $\begin{array}{l}8 \\
0\end{array}$ & 84 & 70 & 84 \\
\hline $\mathrm{C}_{21}$ & 79 & 77 & 86 & 73 & 83 & 81 & 83 & 81 & 85 & 76 & 86 \\
\hline C22 & 81 & 87 & 89 & 75 & 86 & 83 & $\begin{array}{l}8 \\
6\end{array}$ & 83 & 87 & 81 & 88 \\
\hline C23 & 79 & $\begin{array}{l}8 \\
0\end{array}$ & 87 & 73 & 81 & 81 & 81 & 81 & 75 & 60 & 83 \\
\hline C24 & 82 & 63 & 62 & 65 & 63 & 69 & 63 & 69 & 65 & 67 & 76 \\
\hline C25 & 78 & 63 & 83 & 72 & 68 & 60 & $\begin{array}{l}6 \\
8\end{array}$ & 60 & 64 & 78 & 77 \\
\hline C26 & 82 & 68 & 82 & 61 & 72 & 74 & 72 & 74 & 71 & 82 & 76 \\
\hline C27 & 79 & 70 & $\begin{array}{l}8 \\
0\end{array}$ & $\begin{array}{l}6 \\
8\end{array}$ & 68 & 76 & $\begin{array}{l}6 \\
8\end{array}$ & 76 & 70 & 78 & 84 \\
\hline C28 & 83 & 74 & 87 & 77 & 84 & 83 & $\begin{array}{l}8 \\
4\end{array}$ & 83 & 79 & 74 & 89 \\
\hline C29 & 75 & 75 & 75 & 70 & 61 & 75 & 75 & 75 & 75 & 75 & 75 \\
\hline
\end{tabular}

Tabel 6. Matriks ternormalisasi $\mathrm{R}$

\begin{tabular}{|c|c|c|c|c|c|c|c|c|c|c|c|}
\hline & $S_{1}$ & $S_{2}$ & $s_{3}$ & $S_{4}$ & S5 & 56 & S7 & s8 & s9 & $S_{10}$ & $S_{11}$ \\
\hline $\mathrm{C}_{1}$ & 0.875 & 1 & 0.875 & 0.875 & 1 & 0.875 & 0.875 & 0.875 & 0.875 & 0.875 & 0.875 \\
\hline $\mathrm{C}_{2}$ & 0.207 & 0.414 & 0.207 & 0.466 & 1 & 0.45 & $0.08_{1}$ & 0.324 & 0.405 & 0.081 & 0.108 \\
\hline$c_{3}$ & 0.5 & 0.5 & 1 & 0.5 & 0.5 & 1 & 0.5 & 1 & 0.5 & 1 & 0.5 \\
\hline $\mathrm{C}_{4}$ & 。 & 0.5 & 。 & 。 & 1 & 。 & 。 & 0.375 & 0.5 & 0.375 & 0.375 \\
\hline$c_{5}$ & 。 & 0 & 。 & 0.667 & 1 & 0.667 & 0.667 & 0.667 & 1 & 。 & 0.667 \\
\hline C6 & 。 & 。 & 0.5 & 1 & 。 & 0.5 & 。 & 1 & 1 & 。 & 0.5 \\
\hline$c_{7}$ & 。 & 0.5 & 。 & 0.5 & 1 & 。 & 。 & 0.5 & 0.5 & 0 & 0.5 \\
\hline$C B$ & 0.967 & 0.922 & 0.989 & 0.789 & 0.956 & 0.933 & 0.956 & 0.933 & 0.967 & 0.956 & 1 \\
\hline $\mathrm{Cg}_{9}$ & 0.953 & 0.965 & 0.976 & 0.824 & 0.965 & 0.918 & 0.965 & 0.918 & 0.929 & 0.965 & 1 \\
\hline $\mathrm{C}_{10}$ & 0.966 & 0.921 & 1 & 0.843 & 0.933 & 0.91 & 0.933 & 0.91 & 0.899 & 0.787 & 0.955 \\
\hline$C_{11}$ & 0.894 & 0.906 & 0.976 & 0.765 & 0.894 & 0.859 & 0.894 & 0.859 & 0.847 & 0.729 & 1 \\
\hline $\mathrm{C}_{12}$ & 0.904 & 0.862 & 0.979 & 0.787 & 0.894 & 0.819 & 0.894 & 0.819 & 0.734 & 0.819 & 1 \\
\hline $\mathrm{C}_{13}$ & 0.967 & 0.944 & 1 & 0.844 & 0.967 & 0.933 & 0.967 & 0.933 & 0.9 & 0.911 & 0.978 \\
\hline $\mathrm{C}_{14}$ & 0.943 & 0.839 & 0.954 & 0.816 & 0.908 & $0.8_{51}$ & 0.908 & 0.851 & 0.736 & 0.759 & 1 \\
\hline $\mathrm{C}_{15}$ & 0.911 & 0.867 & 0.956 & 0.844 & 0.911 & 0.878 & 0.911 & 0.878 & 0.7 & 0.822 & 1 \\
\hline $\mathrm{C}_{16}$ & 0.953 & 0.906 & 1 & 0.882 & 0.976 & 0.918 & 0.976 & 0.918 & 0.729 & 0.729 & 1 \\
\hline $\mathrm{C}_{17}$ & 0.965 & 0.919 & 1 & 0.837 & 0.942 & 0.872 & 0.942 & 0.872 & 0.942 & 0.698 & 0.919 \\
\hline $\mathrm{C} 18$ & 0.956 & 0.912 & 0.989 & 0.835 & 0.945 & 0.868 & 0.945 & 0.868 & 0.934 & 0.659 & 1 \\
\hline $\mathrm{C}_{19}$ & 0.931 & 0.943 & 1 & 0.862 & 0.954 & 0.897 & 0.954 & 0.897 & 0.966 & 0.782 & 0.954 \\
\hline $\mathrm{C}_{20} \mathrm{O}$ & 0.907 & 0.884 & 1 & 0.837 & 0.953 & 0.93 & 0.953 & 0.93 & 0.977 & 0.814 & 0.977 \\
\hline $\mathrm{C}_{21}$ & 0.919 & 0.895 & 1 & 0.849 & 0.965 & 0.942 & 0.965 & 0.942 & 0.988 & $0.88_{4}$ & 1 \\
\hline $\mathrm{C}_{22}$ & 0.91 & 0.978 & 1 & 0.843 & 0.966 & 0.933 & 0.966 & 0.933 & 0.978 & 0.91 & 0.989 \\
\hline $\mathrm{C}_{23}$ & 0.908 & 0.92 & 1 & 0.839 & $0.93^{1}$ & $0.93^{1}$ & $0.93^{1}$ & $0.93^{1}$ & 0.862 & 0.69 & 0.954 \\
\hline $\mathrm{C}_{24}$ & 1 & 0.768 & 0.756 & 0.793 & 0.768 & 0.841 & 0.768 & 0.841 & 0.793 & 0.817 & 0.927 \\
\hline$C_{25}$ & 0.94 & 0.759 & 1 & 0.867 & 0.819 & 0.723 & 0.819 & 0.723 & 0.771 & 0.94 & 0.928 \\
\hline$C_{26}$ & 1 & 0.829 & 1 & 0.744 & 0.878 & 0.902 & 0.878 & 0.902 & 0.866 & 1 & 0.927 \\
\hline $\mathrm{C}_{27}$ & 0.94 & 0.833 & 0.952 & 0.81 & 0.81 & 0.905 & 0.81 & 0.905 & 0.833 & 0.929 & 1 \\
\hline $\mathrm{C} 28$ & 0.933 & $0.88^{1}$ & 0.978 & 0.865 & 0.944 & 0.933 & 0.944 & 0.933 & 0.888 & $0.8_{31}$ & 1 \\
\hline $\mathrm{C}_{29}$ & 1 & 1 & 1 & 0.933 & 0.813 & 1 & 1 & 1 & 1 & 1 & \\
\hline
\end{tabular}




\subsection{Meranking Alternatif}

Untuk meranking alternatif dilakukan perhitungan menggunakan persamaan (6), sehingga didapat hasil seperti pada tabel 7 .

Tabel 7. Hasil nilai preverensi pada setiap alternatif
Setelah dimasukkan data, maka sistem akan menghitung data penelitian untuk mendapatkan alternatif terbaik dan didapat hasil seperti pada gambar

\begin{tabular}{|c|c|c|c|c|c|c|c|c|c|c|c|}
\hline & $\mathrm{S}_{1}$ & $\mathrm{~S}_{2}$ & $S_{3}$ & $\mathrm{~S}_{4}$ & $\mathrm{~S}_{5}$ & S6 & S7 & S8 & S9 & $\mathrm{S}_{10}$ & $S_{11}$ \\
\hline $\mathrm{C}_{1}$ & 3.259 & 3.725 & 3.259 & 3.259 & 3.725 & 3.259 & 3.259 & 3.259 & 3.259 & 3.259 & 3.259 \\
\hline $\mathrm{C}_{2}$ & 0.767 & 1.533 & 0.767 & 1.733 & 3.7 & 1.667 & 0.3 & 1.2 & 1.5 & 0.3 & 0.4 \\
\hline $\mathrm{C}_{3}$ & 1.9 & 1.9 & 3.8 & 1.9 & 1.9 & 3.8 & 1.9 & 3.8 & 1.9 & 3.8 & 1.9 \\
\hline $\mathrm{C}_{4}$ & $\circ$ & 1.7 & $\circ$ & $\circ$ & 3.4 & $\circ$ & $\circ$ & 1.275 & 1.7 & 1.275 & 1.275 \\
\hline $\mathrm{C}_{5}$ & 0 & $\circ$ & $\circ$ & 2.267 & 3.4 & 2.267 & 2.267 & 2.267 & 3.4 & $\circ$ & 2.267 \\
\hline$C 6$ & $\circ$ & $\circ$ & 1.775 & 3.55 & $\circ$ & 1.775 & $\circ$ & $3 \cdot 55$ & $3 \cdot 55$ & $\circ$ & 1. 775 \\
\hline $\mathrm{C}_{7}$ & 0 & 1.85 & $\circ$ & 1.85 & $3 \cdot 7$ & 0 & $\circ$ & 1.85 & 1.85 & $\circ$ & 1.85 \\
\hline$C 8$ & 4.06 & 3.873 & 4.153 & $3 \cdot 313$ & 4.013 & 3.92 & 4.013 & 3.92 & 4.06 & 4013 & $4 \cdot 2$ \\
\hline $\mathrm{C}_{9}$ & 3.669 & 3.714 & 3.759 & 3,171 & 3.714 & 3.533 & 3.714 & 3.533 & $3.57^{8}$ & 3.714 & 3.85 \\
\hline $\mathrm{C}_{10}$ & $3 \cdot 744$ & 3.57 & 3.875 & 3.265 & 3.614 & 3.527 & 3.614 & 3.527 & $3.48_{3}$ & 3.048 & 3.701 \\
\hline $\mathrm{C}_{11}$ & $3-42$ & 3.465 & $3 \cdot 735$ & 2.925 & 3.42 & 3.285 & 3.42 & 3.285 & 3.24 & 2.79 & 3.825 \\
\hline $\mathrm{C}_{12}$ & 3.436 & $3 \cdot 274$ & $3.7^{19}$ & 2.991 & 3.396 & 3.113 & 3.396 & 3.113 & 2.789 & 3.113 & 3.8 \\
\hline $\mathrm{C}_{13}$ & 3.649 & 3.565 & 3.775 & 3.188 & 3.649 & 3.523 & 3.649 & 3.523 & 3.398 & 3.439 & 3.691 \\
\hline $\mathrm{C}_{14}$ & 3.487 & 3.105 & 3.53 & 3.02 & $3 \cdot 36$ & 3.147 & $3.3^{6}$ & 3.147 & 2.722 & 2.807 & 3.7 \\
\hline $\mathrm{C}_{15}$ & $3.34^{8}$ & 3.185 & 3.512 & 3.103 & $3.34^{8}$ & 3.226 & $3.34^{8}$ & 3.226 & 2.573 & 3.022 & 3.675 \\
\hline $\mathrm{C}_{16} 6$ & 3.574 & 3.397 & 3.75 & 3.309 & 3.662 & 3.441 & 3.662 & 3.441 & 2.735 & 2.735 & 3.75 \\
\hline $\mathrm{C}_{17}$ & $3.577^{1}$ & 3.399 & $3 \cdot 7$ & 3.098 & 3.485 & 3.227 & 3.485 & 3.227 & 3.485 & $2.5^{8}{ }_{1}$ & 3.399 \\
\hline $\mathrm{C}_{1} 8$ & $3.5^{8} 5$ & $3-42$ & 3.709 & $3 \cdot 132$ & 3.544 & 3.255 & $3 \cdot 544$ & 3.255 & 3.503 & 2.473 & 3.75 \\
\hline $\mathrm{C}_{19}$ & 3.422 & 3.464 & 3.675 & 3.168 & 3.506 & 3.295 & 3.506 & 3.295 & 3.548 & $2.88^{2}$ & 3.506 \\
\hline $\mathrm{C}_{20} \mathrm{O}$ & $3 \cdot 65^{1}$ & $3 \cdot 557$ & 4.025 & 3.37 & 3.838 & 3.744 & $3.83^{8}$ & 3.744 & 3.931 & 3.276 & 3.931 \\
\hline $\mathrm{C}_{21}$ & 3.697 & 3.604 & 4.025 & $3 \cdot 417$ & 3.885 & 3.791 & 3.885 & 3.791 & 3.978 & 3.557 & 4.025 \\
\hline $\mathrm{C}_{22}$ & 3.663 & 3.935 & 4.025 & 3.392 & 3.889 & 3.754 & 3.889 & 3.754 & 3.935 & 3.663 & 3.98 \\
\hline $\mathrm{C}_{23}$ & $3 \cdot 7$ & 3.747 & $4 \cdot 075$ & $3-419$ & 3.794 & 3.794 & 3.794 & 3.794 & 3.513 & 2.81 & 3.888 \\
\hline $\mathrm{C}_{24}$ & 4 & 3.073 & 3.024 & 3.171 & 3.073 & 3.366 & 3.073 & 3.366 & $3 \cdot 171$ & 3.268 & 3.707 \\
\hline $\mathrm{C}_{25}$ & 3.524 & 2.846 & $3 \cdot 75$ & 3.253 & 3.072 & 2.711 & 3.072 & 2.711 & 2.892 & 3.524 & 3.479 \\
\hline $\mathrm{C}_{2} 6$ & 3.85 & 3.193 & 3.85 & 2.864 & $3 \cdot 3^{8}$ & $3-474$ & $3 \cdot 3^{8}$ & 3.474 & 3.334 & 3.85 & 3.568 \\
\hline $\mathrm{C}_{27}$ & 3.574 & 3.167 & 3.619 & 3.076 & 3.076 & $3.43^{8}$ & 3.076 & $3.43^{8}$ & 3.167 & 3.529 & 3.8 \\
\hline $\mathrm{C}_{2} 8$ & 3.707 & 3.305 & 3.886 & 3.439 & 3.752 & 3.707 & $3 \cdot 75^{2}$ & 3.707 & 3.528 & 3.305 & 3.975 \\
\hline $\mathrm{C}_{29}$ & 4.025 & 4.025 & 4.025 & 3.757 & 3.274 & 4.025 & 4.025 & 4.025 & 4.025 & 4.025 & 4.025 \\
\hline Total & 86.283 & 86.592 & 92.797 & $8_{5.399}$ & 97.569 & 89.064 & 86.221 & $93-497$ & 91.746 & 80.0497 & 95.951 \\
\hline
\end{tabular}

\subsection{Perancangan Sistem}

Perancangan sistem aplikasi dilakukan berbasis web dengan menggunakan bahasa PHP. Pada tampilan awal berupa tampilan login yang mengharuskan pengguna memasukkan username dan password yang dapat dilihat pada gambar 1 .

\section{Silahkan masuk}

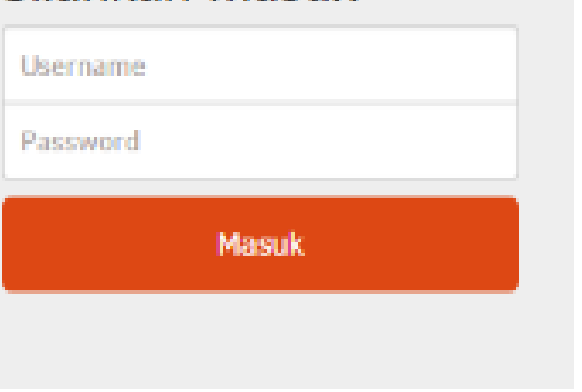

Gambar 1. Tampilan Login

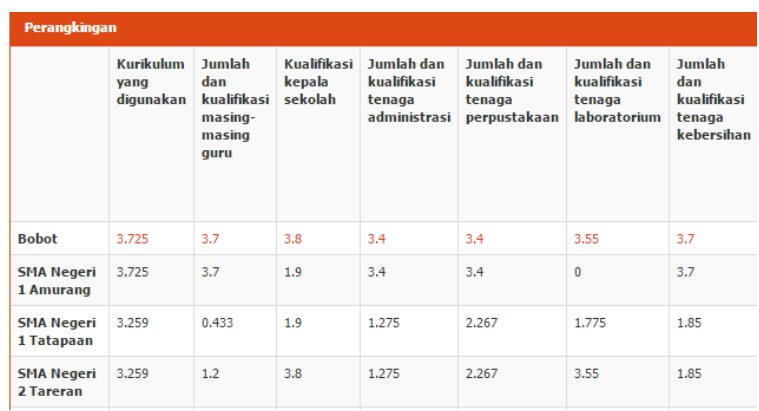

Gambar 2. Tampilan Hasil Analisis dan perankinagan

\subsection{Analisis Hasil}

Didapat Analisis hasil yaitu SMA Negeri 1 Sinonsayang mendapat nilai 86.283 , SMA Negeri 1 Tenga mendapat nilai 86.592, SMA Negeri 1 Amurang Barat mendapat nilai 92.797, SMA Katolik Aquino Amurang mendapat nilai 85.399, SMA Negeri 1 Amurang mendapat nilai 97.569,SMA Negeri 1 Amurang 
Timur mendapat nilai 86.064, SMA Kristen Alfa Omega Tumpaan mendapat nilai 86.221 SMA Negeri 2 Tareran mendapat nilai 93.497,SMA Negeri 1 Tareran mendapat nilai 91.746, SMA Kristen Suluun mendapat nilai 80.050, SMA Negeri 1 Tatapaan mendapat nilai 95.951..

\section{KESIMPULAN DAN SARAN}

\subsection{Kesimpulan}

Dari penelitian ini dapat disimpulkan bahwa:

1. Aplikasi dapat dibangun dan digunakan dalam perankingan Sekolah Menengah Atas (SMA) di Kabupaten Minahasa Selatan menggunakan metode SAW berbasis web.

2. Berdasarkan nilai preferensi (V) pada proses analisis hasil didapat alternatif terbaik yaitu SMA Negeri 1 Amurang dengan nilai 97.569, SMA Negeri 1 Tatapaan dengan nilai 95.951, SMA Negeri 2 Tareran dengan nilai 93.497.

\subsection{Saran}

1. Melihat data hasil, maka diperlukan perhatian pemerintah guna meningkatan kualitas SMASMA di Minahasa Selatan.

2. Perlu adanya penelitian lebih lanjut tentang perankingan dengan menggunakan kriteria lain berdasarkan 8 standar nasional pendidikan.

\section{REFERENSI}

[1] Anisyah. 2009. Analisa dan Desain Sistem Informasi. ANDI, Yogyakarta.

[2] Anonim. 2003. Undang-Undang Republik Indonesia Nomor 20 Tahun 2003 Tentang Sistem Pendidikan Nasional. https://kemenag.go.id/file/dokumen/UU2003.pd f. [25 Oktober 2018]

[3] Anonim. 2012. Kabupaten Minahasa Selatan. http://loketpeta.pu.go.id/peta-infrastrukturkabupaten-minahasa-selatan-2012 [14 September 2015]

[4] Anonim. 2016. Peraturan Pemerintah Republik Indonesia Nomor 32 Tahun 2013. http://kelembagaan.ristekdikti.go.id/wpcontent/uploads/2016/o8/ PP0322013.pdf. [25 Oktober 2018]

[5] Anonim. 2019. Kabupaten Minahasa Selatan Dalam Angka 2019. Badan Pusat Statistik Kabupaten Minahasa Selatan, Amurang.

[6] Friyadie. 2017. Penggunaan Metode Simple Additive Weighting Penentuan Kelayakan Pemberian Beasiswa Untuk Siswa Berprestasi. Jurnal Ilmu Pengetahuan dan Teknologi Komputer 3(1):17-22.

[7] Kusumadewi, S. 2006. Fuzzy Multi-Attribute Decision Making (FUZZY MADM). Graha Ilmu, Yogyakarta.

[8] Ontah, G. M., W. C. D. Weku dan A. J. Rindengan. 2014. Sistem Pendukung Keputusan Dalam Memetakan Wilayah Risiko Banjir Menggunakan
Fuzzy Multi Criteria Decision Making. Jurnal d'CartesiaN 3(2):24-30.

[9] Pareda, S., C. E. Mongi dan C. E. J. C. Montolalu. 2019. Sistem Pendukung Keputusan Pemilihan Karyawan Teladan di PT Aneka Tambang (ANTAM) Tbk Unit Bisnis Pertambangan Buli Menggunakan Metode Simple Additive weight (SAW). Jurnal d'CartesiaN 8(1):1-10.

[10] Purwanto,C., D. Hatidja dan M. Paendong. 2015. Pemetaan SMA/SMK di Kab. Minahasa Tenggara Berdasarkan Empat Indikator Standar Nasional Pendidikan Dengan Mengunakan Analisis Biplot. Jurnal d'CartesiaN 4(1): 34-41.

[11] Sutarman. (2004). Dasar Pemrograman Web Dinamis menggunakan PHP. ANDI, Yogyakarta.

[12] Taogan, Y.A., M. Paendong dan C.E. Mongi. 2016. Pemetaan Sma Di Kabupaten Minahasa Selatan Berdasarkan Standar Isi, Standar Pendidik Dan Tenaga Kependidikan, Standar Kompetensi Lulusan, Dan Standar Penilaian Pendidikan Dengan Menggunakan Analisis Biplot. Jurnal d'CartesiaN 5(1): 13-20.

\section{Handra R. Sagrang}

(handra282@gmail.com)

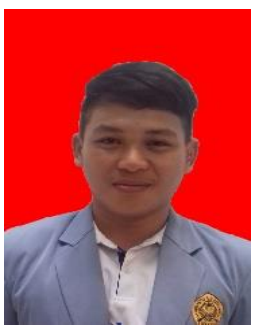

lahir dan tinggal di desa Talaitad, Kec. Suluun Tereran, Kab. Minahasa Selatan, Prov. Sulawesi utara. Menempuh pendidikan tinggi Program Studi Matematika dan Ilmu Pengetahuan Alam Universitas Sam Ratulangi Manado. Tahun 2019 adalah tahun terakhir ia menempuh studi. Makalah ini merupakan hasil penelitian

skripsinya yang di publikasikan.

Altien J. Rindengan

(altien@unsrat.ac.id)

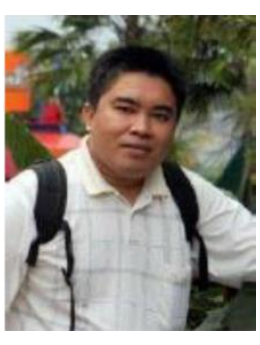

Lahir di Tinoor, pada tanggal 27 April 1974. Pada tahun 1999 memperoleh gelar Sarjana di Departemen Matematika, Fakultas Matematikan dan Ilmu Pengetahuan Alam, Institut Pertanian Bogor. Gelar Magister Ilmu Komputer diperoleh dari Departemen Ilmu Komputer, Institut Pertanian Bogor, pada tahun 2012. Sejak tahun 2001 menjadi pengajar di jurusan Matematika, Fakultas Matematika dan Ilmu Pengetahuan Alam, Universitas Sam Ratulangi Manado. Fokus penelitian-penelitian yang dilakukan adalah Riset Operasi, Sistem Pendukung Keputusan, Sistem Fuzzy, Image Proccesing. 
Penerapan Metode SAW (Simple Additive Weighting) Pada Perankingan SMA-SMA Di Kabupaten Minahasa Selatan

d'Cartesian Jurnal Matematika dan Aplikasi, Vol. 9, No. 1, (Maret 2020): 16-23

Marline S. Paendong

(Marline Paendong@yahoo.com)

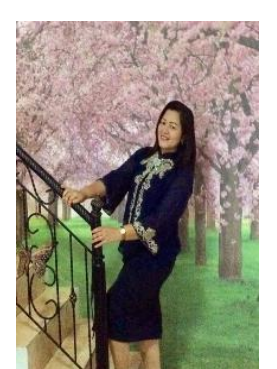

Pada tahun 1999, memperoleh gelar

sarjana di Program Studi

Matematika, Universitas Gadjah

Mada. Gelar magister Sains

diperoleh di Institut Pertanian Bogor pada tahun 2006. Ia bekerja di UNSRAT di Program Studi Matematika sebagai pengajar akademik tetap. 